\title{
Influence of Daily Penicillin, Tetracycline, Erythromycin, and Sulphamethoxypyridazine on Exacerbations of Bronchitis
}

\author{
A Report to the Research Committee of the British Tuberculosis Association*
}

\author{
PREPARED BY R. S. FRANCIS, † M.D., M.R.C.P. ; J. R. MAY, $\ddagger$ M.D.; C. C. SPICER,§ M.R.C.S., L.R.C.P.
}

The role of antibiotics in bronchitis has been the subject of two previous double-blind investigations by this committee, carried out by a large number of chest physicians throughout urban and rural areas of England, Wales, and Scotland. In the first trial (British Tuberculosis Association, 1960) tetracycline $250 \mathrm{mg}$. and penicillin $\mathrm{V}$ potassium $312 \mathrm{mg}$., administered twice daily from January to April 1959, appeared to be equally effective in halving the days lost from work due to bronchitis as compared with an inert control capsule (one week as against two).

The second trial (British Tuberculosis Association, 1961) was more elaborate and set out to compare the effectiveness of the daily antibiotic regimens of the first trial with alternative regimens consisting of intermittent high-dose medication with these same antibiotics at the onset of respiratory symptoms. The result of this trial showed a superiority of the daily tetracycline regimen (four days lost owing to bronchitis as against eight or nine in the other three groups). It was thought that the intermittent regimens might have been associated with fewer days off work if patients had carried out the instructions more effectively. Daily tetracycline was the only regimen associated with a significant fall in the isolation rate of Haemophilus influenzae from sputum specimens examined in mid-trial, whereas pneumococcus isolations fell in all four regimens. It was concluded that since daily tetracycline medication had been as effective as daily penicillin in the first trial, and clearly more effective in the second, then it should be considered the drug of choice, an opinion strongly supported by the significant reduction in $H$. influenzae isolations. It was thought, however, that further investigation should be undertaken especially in view of the high cost of tetracycline. The price of tetracycline has since been reduced.

\section{Present Investigation}

The experiment was designed to compare the effectiveness of a number of therapeutic substances when administered twice daily throughout the winter as in the first trial, omitting any form of intermittent treatment but incorporating the same bacteriological study as the second trial. Once more the doubleblind technique was employed, but ethical considerations prevented the inclusion of a control group.

\section{Materials and Methods}

The following daily regimens were employed:

$$
\text { Regimen }
$$

1: Erythromycin estolate

Sulphamethoxypyridazine

Tetracycline

: Mixture of 6: Tetracycline
Erythromycin $\ldots$ estolate

Sulphethoxypyridazine

potassium
Total Daily Dose

$100 \mathrm{~g}$.

.

$500 \mathrm{~g}$.

$250 \mathrm{mg}$.

$500 \mathrm{mg}$.

$624 \mathrm{mg}$.
The total daily dose in each case was presented in four capsules, two to be taken twice daily. All capsules were externally indistinguishable.

Regimens 5 and 6 were included because they had been employed in previous trials and because further experience of their effect was regarded as basic to the whole investigation. Regimen 3 was employed to see whether by doubling the dose of tetracycline more effective suppression of $H$. influenzae could be brought about, and if so whether this would be reflected in greater clinical benefit. Regimen 1 was thought desirable since erythromycin is also effective in vitro against $H$. influenzac. In view of certain claims for the effectiveness of sulphonamides in bronchitis, it was thought expedient to include regimen 2 . Regimen 4 was introduced in view of the possibility of synergic action and also because possible side-effects of both drugs might be kept to a minimum by employing a half-dose of each.

The organization and objects of the trial were essentially those of the preceding trials. Employed male bronchitics were to be allocated at random to the six regimens, the effectiveness of which was to be compared in terms of days unfit for work in consequence of respiratory infection per 100 days exposed. Chest physicians throughout urban and rural England, Wales, and Scotland co-operated in a centrally directed double-blind trial. Up to 12 bronchitics were asked to take part in each clinic, and were listed numerically 1 to 12 in order of enrolment.

The medicaments representing the six regimens were encapsulated and bottled at the factory of Messrs. Eli Lilly, and labelled with the letters $A$ to $F$. They were dispatched before the trial to the participating clinics with a sheet containing the order of allocation to the nominal list of patients. In case some clinics were unable to recruit their full quota of patients, the order was varied twice to ensure a roughly equal distribution of patients among the regimens.

The method of selecting patients suitable for the trial was identical with that of the two earlier trials except that the lower age limit was abolished. They were to be men in employment, up to the age of 65 , who had had winter cough and sputum containing pus during exacerbations for three years or more, during which time they had lost work on at least two occasions because of these symptoms. Chest physicians were asked to recruit patients who seemed likely to co-operate in the trial. Patients were not suitable for the trial if their main symptom was wheezing without cough or sputum, if there was no pus in the sputum during exacerbations, if they had been in heart failure, if they had radiographic changes other than those due to bronchitis and emphysema, if they had some other disability likely to cause prolonged loss of work, or if they had a history

\footnotetext{
* From its Bronchitis Subcommittee, whose members are: Dr. P. Baldry, Dr. R. S. Francis (secretary), Dr. Robert May, Dr. E. N. Moyes (chairman), Mr. P. D. Oldham, and Dr. C. C. Spicer. † Whipps Cross Hospital and Chest Clinic, London. ¥ Institute of Diseases of the Chest, London.

Present address: General Register Office, Somerset House, London.
} 
of penicillin hypersensitivity. Chest physicians made monthly assessments of progress based on health visitors' reports, monthly interviews, and patients' diaries, and once again the co-operation of the general practitioners was sought; the ultimate responsibility for the patients remained theirs and they were requested to write in the diaries the name of any antibiotics prescribed during the course of the trial. Patients were told to continue taking the trial capsules in addition to any treatment prescribed by their doctors. The number of such treatments was included in the analysis.

Chest physicians were asked to record the days on which patients were unfit for work as a consequence of (1) bronchitis or pneumonia (" relevant illness"); (2) other respiratory conditions, excluding tuberculosis or new growth; and (3) other causes. They were also asked to record the number of exacerbations of bronchitis as defined by "an increase of cough with the appearance of pus in the sputum, or an increase in the amount of pus over the amount usually present." Side-effects were recorded and also days when patients failed to satisfy the criteria of the trial; for example, by not taking the capsules or by being unemployed. Before the trial, data were recorded concerning weight, age, type of occupation, (indoor or outdoor), and the time of sputum production (morning, daytime, or both). At the end of the trial weight was again recorded, together with the number of cigarettes smoked per day.

\section{Laboratory Organization}

The arrangements for collection and examination of sputum specimens and the laboratory techniques employed were essentially the same as those used in the second trial (British Tuberculosis Association, 1961). The following is a brief summary.

Laboratory examination of sputum was carried out during (a) the week preceding the trial, (b) a week in the middle, and $(c)$ the second week after its end. Three fresh specimens from each patient were examined on each occasion. The cultures for patients attending 13 clinics in or near London were carried out in the bacteriology laboratory of the Institute of Diseases of the Chest ; those for patients attending 39 clinics outside London were carried out in the laboratory normally serving each clinic. In each instance the cultures were made on the day the sputum was expectorated.

\section{Sputum-culture Technique}

All bacteriologists were asked to make their sputum cultures after preliminary liquefaction with pancreatin, in order to standardize the technique. In the light of the conclusions of the previous trial (May and May, 1963) and of earlier observations (May, 1958) attention was paid only to the isolation of $H$. influenzae and pneumococci.

\section{Testing of Sensitivity of Bacteria to Antibacterial Drugs}

As in the previous trial, all sensitivity tests were carried out In the laboratory of the Institute of Diseases of the Chest, to which cultures or organisms isolated in provincial laboratories were sent. Strains of $H$. influenzae were tested against each of the drugs used in the trial. Pneumococci, however, were investigated only in respect of erythromycin and sulphamethoxypyridazine; their sensitivity to penicillin and tetracycline was accepted as invariable.

Sensitivity was estimated by titration on a solid medium (agar containing $\mathrm{X}$ and $\mathrm{V}$ factors) in Petri dishes. To the medium used for testing sensitivity to sulphamethoxypyridazine $0.5 \%$ horse blood was added in order to neutralize substances in nutrient agar inhibitory to sulphonamides (Mackie and McCartney, 1960). The organisms were "spotted" on to sets of plates containing varying concentrations of the drugs, 16 strains being thus tested on each set. The concentrations of drugs used were:

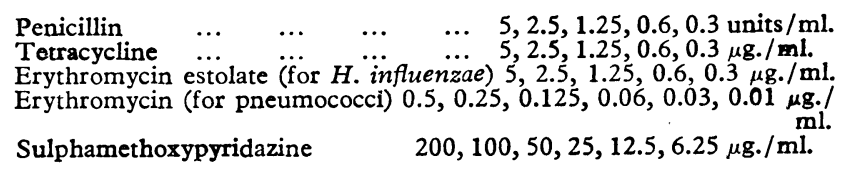

The sensitivity of each strain was recorded as the lowest concentration of antibiotic causing complete inhibition of growth.

\section{Clinical Results}

The trial started on 30 October 1961 and ended on 18 March 1962 , covering a period of 140 days. Fifty-six chest physicians and their colleagues recruited 520 patients, of whom 14 proved uncooperative and never entered the trial. One failed to enter because of a misunderstanding. Four did not conform to the protocol, two having received additional daily antibiotics from their doctors, one being allergic to penicillin and tetracycline, and one having carcinoma of the bronchus. Twenty-one patients were sick and off work before the trial started and remained so for the whole period, and in three cases the information received was inadequate. The number actually entering the trial was thus 477 , but seven of these withdrew in the first two weeks because of toxic symptoms and have not been included in the main analysis, leaving 470 cases on which the study is based. A summary of those omitted is given in Table I.

TABLE I.-Numbers of Patients Omitted from Analysis and Reasons for

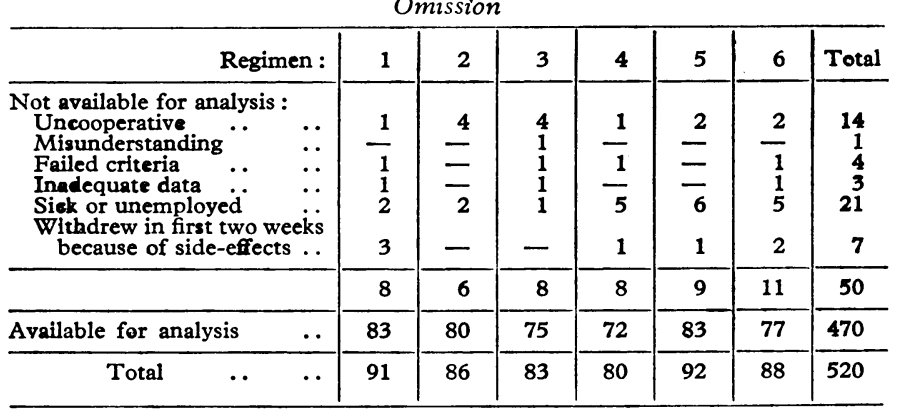
Regimens. 1 Erythromycin estolate. 2x Sulphamethoxypyridazine. 3=Tetracycline: high dose. $4=$ Erythromycin estolate + sulphamethoxypyridazine.
$5=$ Tetracycline : low dose. $6=$ Penicillin.

The clinical results in the 470 cases analysed are summarized in Table II, which shows the average days lost per 100 exposed from various types of respiratory disease on each regimen. It can be seen that sulphamethoxypyridazine was the least effective drug, while the differences between the others are much less marked. The variability of the responses is very large, and the only feature that is statistically significant is the greater number of days lost from all respiratory disease on the sulphonamide regimen, as judged by the significance test for the largest deviation of a set of means (Biometrika Tables 1958, Table 26, $P=0.01$ ). However, this compound was consistently the worst in each month of the trial, as can be seen in Table III, which shows the days lost from bronchitis and pneumonia by months. In addition, the number of antibiotic treatments received by

TABI.E II.-Average Days Off Per 100 Days Exposed From Different Forms of Respiratory Disease on Each Regimen

\begin{tabular}{|c|c|c|c|c|c|c|}
\hline Regimen : & 1 & 2 & 3 & 4 & 5 & 6 \\
\hline 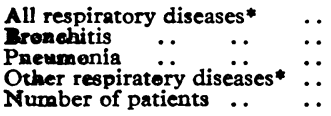 & $\begin{array}{c}12 \cdot 2 \\
10 \cdot 7 \\
0 \\
1 \cdot 5 \\
83\end{array}$ & $\begin{array}{r}19 \cdot 6 \\
15 \cdot 6 \\
0 \cdot 1 \\
3.9 \\
80\end{array}$ & $\begin{array}{r}13 \cdot 0 \\
10 \cdot 3 \\
0 \cdot 3 \\
2 \cdot 4 \\
75\end{array}$ & $\begin{array}{r}14 \cdot 3 \\
12 \cdot 1 \\
0 \cdot 2 \\
1 \cdot 9 \\
72\end{array}$ & $\begin{array}{c}10 \cdot 4 \\
9 \cdot 6 \\
0 \\
0 \cdot 8 \\
83\end{array}$ & $\begin{array}{c}11 \cdot 3 \\
10 \cdot 3 \\
0 \\
0.9 \\
77\end{array}$ \\
\hline
\end{tabular}

*:Excluding tuberculosis and neoplasm. 
patients from their general practitioners was greater on this regimen than on any other (Table IV).

TABle III.-Average Days Off Per 100 Days Exposed From Bronchitis and Pneumonia ("Relevant Illness") for Each Month of the Trial, on Each Regimen

\begin{tabular}{|c|c|c|c|c|c|c|c|c|}
\hline & & Regimen: & 1 & 2 & 3 & 4 & 5 & 6 \\
\hline $\begin{array}{l}\text { November } \\
\text { December } \\
\text { January } \\
\text { February } \\
\text { March }\end{array}$ & $\begin{array}{l}\cdots \\
\cdots \\
\cdots \\
\cdots\end{array}$ & $\begin{array}{l}\cdots \\
\cdots \\
\cdots \\
\cdots\end{array}$ & $\begin{array}{r}3.2 \\
10.0 \\
13.7 \\
7.9 \\
8.8\end{array}$ & $\begin{array}{r}6 \cdot 0 \\
13 \cdot 1 \\
22 \cdot 8 \\
18 \cdot 1 \\
16 \cdot 7\end{array}$ & $\begin{array}{r}2 \cdot 9 \\
8 \cdot 8 \\
15 \cdot 9 \\
12 \cdot 7 \\
13.9\end{array}$ & $\begin{array}{r}5 \cdot 4 \\
13 \cdot 1 \\
14 \cdot 3 \\
13 \cdot 4 \\
12 \cdot 2\end{array}$ & $\begin{array}{r}3.6 \\
7.6 \\
16.0 \\
9 \cdot 3 \\
10.6\end{array}$ & $\begin{array}{r}3.0 \\
7 \cdot 2 \\
19 \cdot 4 \\
13 \cdot 6 \\
12.5\end{array}$ \\
\hline
\end{tabular}

TABle IV.-Average Number of Treatments Per Patient Received from General Practitioners, on each Regimen

\begin{tabular}{|c|c|c|c|c|c|c|c|}
\hline & Regimen : & 1 & 2 & 3 & 4 & 5 & 6 \\
\hline G.P. treatments & . & $0 \cdot 24$ & 0.51 & 0.25 & 0.44 & $0 \cdot 25$ & 0.28 \\
\hline
\end{tabular}

Taking all these facts together, it seems reasonable to conclude that sulphamethoxypyridazine is a less effective medication, in the circumstances of the trial, than the others. The relative efficacy of the other five cannot be accurately assessed with the number of patients available.

As in previous trials, the number of attacks of relevant illness appeared to be unaffected by the various drugs. The average numbers of attacks of these and other respiratory disease are given in Table V. The differences between the regimens are not statistically significant. The average number of days off per attack for all respiratory disease is given in Table VI. It can be seen that, measured in this way, the sulphonamide regimen is still the worst.

TABLE V.-Average Number of Attacks of Bronchitis and Pneumonia, and Other Respiratory Disease Per Patient on Each Regimen

\begin{tabular}{|c|c|c|c|c|c|c|}
\hline Regimen : & 1 & 2 & 3 & 4 & 5 & 6 \\
\hline $\begin{array}{l}\text { Bronchitis and pneumonia } \\
\text { Other respiratory disease }\end{array}$ & $\begin{array}{l}0.81 \\
0.33\end{array}$ & $\begin{array}{l}0.76 \\
0.37\end{array}$ & $\begin{array}{l}0 \cdot 88 \\
0 \cdot 40\end{array}$ & $\begin{array}{l}0 \cdot 71 \\
0 \cdot 24\end{array}$ & $\begin{array}{l}0.63 \\
0 \cdot 27\end{array}$ & $\begin{array}{l}0.73 \\
0.40\end{array}$ \\
\hline
\end{tabular}

Table VI.-Average Days Off Per 100 Days Exposed Per Attack for All Respiratory Disease

\begin{tabular}{r|c|c|c|c|c|c}
\hline Regimen : & 1 & 2 & 3 & 4 & 5 & 6 \\
\hline Average days off per attack.. & $10 \cdot 8$ & $17 \cdot 2$ & $10 \cdot 1$ & $15 \cdot 1$ & $11 \cdot 7$ & $10 \cdot 0$ \\
\hline
\end{tabular}

As mentioned above, a number of characteristics such as age and smoking habits were recorded for each patient. These might have had some bearing on their response to treatment if, by an accident of randomization, they were very unevenly distributed among the regimens. The distributions of these factors are summarized in Table VII: there is no particular feature which would account for the inferiority of sulphonamide, and none of the differences are statistically significant.

TABle VII.-Distribution of Some Characteristics of the Patients Among TABLE VII.-Distribution of So Six Regimens

\begin{tabular}{l|c|c|c|c|c|c|c}
\hline Regimen : & 1 & 2 & 3 & 4 & 5 & 6 & $\begin{array}{c}\text { All } \\
\text { Regi- } \\
\text { mens }\end{array}$ \\
\hline $\begin{array}{l}\text { Average age } \\
\text { Weight change } \\
\text { (lb.) }\end{array}$ & 55.5 & 53.4 & 55.0 & 54.5 & 54.7 & 54.7 & 54.6 \\
$\begin{array}{l}\text { Tobacco } \\
\text { (oz./wk.) }\end{array}$ & 8.54 & +1.42 & +0.81 & +1.53 & +1.43 & +1.22 & +1.15 \\
$\begin{array}{c}\text { \% indoor } \\
\text { workers .. }\end{array}$ & 72.1 & 70.1 & 69.2 & 66.2 & 60.8 & 60.5 & 66.4 \\
\hline
\end{tabular}

\section{Side-effects}

The main side-effects reported were mild gastro-intestinal symptoms such as nausea and frequent motions occasionally amounting to diarrhoea. There were a few other complaints such as dyspnoea and bronchospasm which could not definitely be attributed to the drugs employed. In only a third of the patients affected could the side-effects be regarded as moderately severe, and in only three cases as severe. Of these one patient on penicillin withdrew after two weeks because of depression, dyspnoea, and malaise, which cleared up after withdrawal of the capsules. Another, on the higher dose of tetracycline, withdrew after 31 days because of nausea and vomiting; and the third, on erythromycin, withdrew after 31 days because of aggravation of his peptic ulcer. The results are summarized in Table VIII.

TABLE VIII.-Frequency of Various Types of Side-effect in Patients on

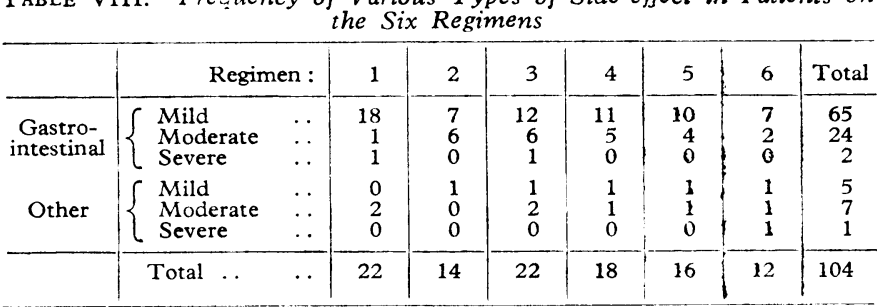

\section{Deaths}

Seven deaths occurred during the trial, one in a patient who was not in the analysis. One death was due to bleeding peptic ulcers, and six to cardiac failure resulting from chest disease. In five of these cases the cause of death was explicitly stated by the chest physician and in one case the cause was clearly implied by the clinical description.

Case 04/04. Regimen : Erythromycin estolate and sulphonamide. -Died on 21 February 1962 as a result of bleeding peptic ulcers.

Case 19/08. Regimen : Erythromycin estolate and sulphonamide. -Not eligible for analysis (off work since before trial). Died of cor pulmonale in February 1962.

Case 23/02. Regimen: Erythromycin estolate and sulphonamide. -Died of chronic bronchitis and congestive cardiac failure on 28 December 1962.

Case 28/09. Regimen : Tetracycline (low dose).-Stopped capsules on 23 November 1961, no reason being given. Died of bronchopneumonia and cardiac failure on 11 January 1962.

Case 43/10. Regimen: Sulphamethoxypyridazine.-Stopped capsules from 1 to 21 November 1961 and again from 23 November until he died from congestive cardiac failure on 26 December 1961. He thus took the capsules for only two days on each of two occasions. The chest physician reported that, possibly as a result of the antibiotic, the patient had great difficulty in expectorating thick viscid and tenacious sputum, and went rapidly into congestive cardiac failure and died.

Case 54/06. Regimen : Erythromycin estolate and sulphamethoxypyridazine.-Complained of increasing dyspnoea, cough, and white sputum and was admitted to hospital on 11 December 1961. $\mathrm{He}$ was found to be cyanosed and dyspnoeic, with bilateral basal rales, and rhonchi over the whole of the lung fields, and was given tetracycline and later penicillin. Oxygen and digitalis treatment was followed by considerable improvement, but he relapsed and died after gradual deterioration.

Case 32/03. Regimen: Erythromycin estolate.-Stopped work on 15 November 1961 because of bronchitis. Admitted to hospital on 2 January 1962 and died of congestive cardiac failure, cor pulmonale, and chronic bronchitis on 7 January. He had stopped taking the capsules on 18 December 1961, or 21 days before he died.

\section{Bacteriological Results}

The isolation rates of $H$. influenzae and pneumocacci at the beginning of the trial were essentially the same as in the trial of 1959-60. Table IX shows the isolation rates for both years; the prevalence of each organism in purulent and mucoid sputa is also shown. No distinction is made between findings in London and the provinces ; in the current trial, as in the earlier 
one, the rates for $H$. influenzae were in fact higher in London, and possible explanations for the difference have been discussed in the previous reports (British Tuberculosis Association, 1961 ; May and May, 1963).

TABLE IX.-Pre-trial Isolation Rates of $H$. influenzae and Pneumococci from Sputum in Trials of 1959-60 and 1961-2 (All Clinics Combined)

\begin{tabular}{c|c|c|c|c}
\hline Organism & $\begin{array}{c}\text { Year } \\
\text { of } \\
\text { Trial }\end{array}$ & \multicolumn{2}{|c|}{$\begin{array}{c}\text { No. of Patients from whom a } \\
\text { Pathogen was Isolated }\end{array}$} & $\begin{array}{c}\text { Total } \\
\text { Patients }\end{array}$ \\
\cline { 3 - 4 } $\begin{array}{c}\text { influenzae } \\
\text { Pneumo- }\end{array}$ & $\begin{array}{c}\text { Patients with } \\
\text { Purulent Sputum }\end{array}$ & $\begin{array}{c}\text { Patients with } \\
\text { Mucoid Sputum }\end{array}$ & \\
cocci & $1959-60$ & $93 / 274(34 \%)$ & $23 / 129(19 \%)$ & 403 \\
& $1961-2$ & $120 / 321(37 \%)$ & $26 / 112(23 \%)$ & 433 \\
$1959-60$ & $120 / 274(44 \%)$ & $46 / 129(36 \%)$ & 403 \\
$1961-2$ & $120 / 321(37 \%)$ & $31 / 112(28 \%)$ & 433 \\
\hline
\end{tabular}

Note: The denominator of each fraction indicates the number of patients in the group; the numerator is the number from whom the relevant organisms was
isolated.

Tables $\mathrm{X}$ and $\mathrm{XI}$ show the isolation rates at each stage of the trial of $H$. influenzae and pneumococci in the six treatment groups. Tetracycline was the only drug associated with a statistically significant fall in the prevalence of $H$. influenzae in the middle of the trial ; the customary relapses of infection, however, occurred after the end of the trial, as indicated by the rise in isolation rates. In contrast, pneumococci were significantly reduced in number by all drugs except sulphamethoxypyridazine, but their behaviour differed from that of their counterparts in the trial of 1959-60 in that, after treatment was stopped, their numbers tended to return to the pretreatment figures. This trend was apparent in each treatment group and is most unusual for this organism.

TABLE X.-Isolation Rates of $H$. influenzae From Sputum on Different Regimens (All Clinics Combined)

\begin{tabular}{|c|c|c|c|c|c|c|}
\hline \multirow{2}{*}{$\begin{array}{l}\text { Stage } \\
\text { of } \\
\text { Trial }\end{array}$} & \multicolumn{6}{|c|}{ Regimen } \\
\hline & 1 & 2 & 3 & 4 & 5 & 6 \\
\hline $\begin{array}{l}\text { Beginning } \\
\text { Middle } \\
\text { End } \quad .\end{array}$ & $\begin{array}{l}23 / 79(29) \\
19 / 64(30) \\
27 / 68(40)\end{array}$ & \begin{tabular}{|l|}
$22 / 80(26)$ \\
$10 / 61(16)$ \\
$16 / 64(25)$
\end{tabular} & \begin{tabular}{|r|}
$22 / 71(31)$ \\
$6 / 60(10)$ \\
$14 / 59(24)$
\end{tabular} & $\begin{array}{l}25 / 74(34) \\
15 / 59(25) \\
15 / 65(23)\end{array}$ & $\begin{array}{r:r}25 / 80(31) \\
9 / 69(13) \\
13 / 70(19)\end{array}$ & $\begin{array}{l}28 / 77(38) \\
21 / 66(32) \\
18 / 67(27)\end{array}$ \\
\hline
\end{tabular}

TABLE XI.-Isolation Rates of Pneumococci from Sputum of Patients on Different Regimens (All Clinics Combined)

\begin{tabular}{|c|c|c|c|c|c|c|}
\hline \multirow{2}{*}{$\begin{array}{l}\text { Stage } \\
\text { of } \\
\text { Trial }\end{array}$} & \multicolumn{6}{|c|}{ Regimen } \\
\hline & 1 & 2 & 3 & 4 & 5 & 6 \\
\hline $\begin{array}{l}\text { Beginning } \\
\text { Middle } \\
\text { End } \quad \cdots\end{array}$ & \begin{tabular}{|c|}
$32 / 79(41)$ \\
$3 / 64(5)$ \\
$14: 68(21)$
\end{tabular} & $\mid \begin{array}{lll}29 / 80 & (36) \\
20 / 61 & (33) \\
21 / 64 & (33)\end{array}$ & \begin{tabular}{|c|c|}
$26 / 71$ & $(37)$ \\
$3 / 60$ & $(5)$ \\
$12 / 59$ & $(20)$ \\
\end{tabular} & \begin{tabular}{|r|}
$22 / 74(30)$ \\
$8 / 59(14)$ \\
$18 / 65(28)$
\end{tabular} & $\begin{array}{c}25 / 80(31) \\
6 / 69(9) \\
14 / 70(20)\end{array}$ & $\begin{array}{c}32 / 77(42) \\
6 / 66(9) \\
15 / 67(22)\end{array}$ \\
\hline
\end{tabular}

No significant change in the sensitivity of $H$. influenzae to any of the drugs was detected, but it was disturbing to find six strains of pneumococcus resistant to more than $5 \mu \mathrm{g}$. of erythromycin per $\mathrm{ml}$. at the end of the trial. Five of these were isolated in patients who received erythromycin and sulphamethoxypyridazine. The sixth came from a patient given tetracycline. This was surprising, since crossed resistance between tetracycline and erythromycin is said not to occur.

\section{Discussion}

The main clinical finding of the present trial is the inferiority of sulphamethoxypyridazine in relation to the other five regimens. There may, however, be smaller differences between the latter which are concealed by the variability of response.
The bacteriological findings are essentially in agreement with the clinical ones. The outstanding feature was the failure of sulphamethoxypyridazine to influence the carriage of either $H$. influenzae or pneumococci while each of the other regimens exerted a suppressive action on one or both organisms.

In the first trial sputum cultures were not carried out ; since daily penicillin and daily tetracycline appeared equally good clinically, it was thought that the effect of both regimens had been to suppress only the pneumococci, the dose of tetracycline being regarded as too small to have had any effect on the haemophilus. Bacteriological studies of sputum in the second and third trials showed that this explanation was incorrect, since the same daily dose of tetracycline led to a significant depression of the haemophilus isolations. In the third trial clinical benefit was associated with the suppression of pneumococci by antibiotics-for example, penicillin-which had no effect on $H$. influenzae, and the suppression of the latter by tetracycline appears to have led to no additional clinical advantage. In the second trial, however, the penicillin regimen proved a relative failure clinically despite the suppression of pneumococci, and it is concluded that pneumococci were important pathogens during the first and third trials but not during the second (see May and May, 1963). It seems that there is need for further study of pneumococci in relation to bronchitis; it may well be that certain serological types are more pathogenic than others in this condition and that their prevalence fluctuates from year to year. It must be remembered that in all three trials the effect has been on the duration of exacerbations rather than their incidence, but we are unable to say whether this, or the reduction of bacterial pathogens during the trial, is capable of influencing the long-term prognosis.

On the evidence of the present trial the sulphonamide is definitely less effective than the other preparations and there is no justification for its use. Experience in these trials so far has shown that the most effective regimen is one capable of suppressing both pneumococci and $H$. influenzae; tetracycline is the only antibiotic tested which possesses this property. The effect of erythromycin appears to be comparable with that of penicillin, but additional work would be required to confirm this. Furthermore, the finding that highly resistant strains of pneumococci appeared during medication with erythromycin estolate combined with a sulphonamide, a regimen which was not superior to other drugs clinically, is a clear contraindication to its long-term use in chronic bronchitis.

\section{Summary}

A double-blind controlled trial was carried out during the winter of 1961-2 to compare the efficacy of penicillin, tetracycline, erythromycin estolate, and sulphamethoxypyridazine in bronchitic exacerbations when administered continuously.

Sulphamethoxypyridazine appeared to be less effective than the other regimens, but the variability in response did not allow an assessment of the relative efficacy of the latter.

Bacteriological findings showed significant suppression of Haemophilus influenzae by tetracycline, and of pneumococci by all regimens except sulphamethoxypyridazine.

The similar efficacy of tetracycline and the other antibiotic regimens suggested that pneumococci were important pathogens during the period of this trial.

We are indebted to Mr. H. R. Simpson, of the statistics department, Rothamsted Experimental Station, for his help in the analysis of this trial on the electronic computer there. We are grateful to Joyce White, Barbara Bavester, and Brenda Moore for secretarial assistance, and to Doreen Delves, Beryl Godden, and Alan Schneider for technical help.

We wish also to record our appreciation to Messrs. Eli Lilly for supplies of penicillin- $\mathrm{V}$ potassium (" $\mathrm{V}$ Cil $\mathrm{K}$ ") and erythromycin estolate ("ilosone"), and to Messrs. Lederle for supplies of sulpha- 
methoxypyridazine ("lederkyn") and tetracycline ("achromycin"); and to both firms for a grant towards the expenses of the trial. To Messrs. Eli Lilly we express our thanks for their invaluable assistance in the preparation, bottling, and distribution of the capsules in code numbers to the participating chest clinics. It is a particular pleasure to thank all the chest physicians, their staffs and health visitors, the bacteriologists, and general practitioners for their tireless co-operation.

The names of the participating chest physicians are given below, together with the clinics and hospitals at which the investigation was carried out.

Altrincham: Dr. A. Fleming. Ashford: Dr. P. Baldry, Dr. G. P. Rooke. Ayrshire (Northern) Hospitals: Ayrshire Central Hospital: Dr. G. T. Boyd Dr. A. M. Mechie; Heathfield Chest Clinic: Dr. J. W. N. Duerden; Kilmarnock Infirmary: Dr. L. A Hardie. Balham Chest Duerden; Kilmarnock Infirmary: Dr. L. A. Hardie. Balham Chest Clinic: Dr. P. C. Anderson, Dr. L. A. S. Trott. Barnet Chest Clinic: pital: Dr. H. J. T. Ross. Bournemouth Chest Clinic: Dr. W. H. Tattershall. Brentwood Chest Clinic: Dr. E. Woolf. Bristol Chest Clinic: Dr. A. T. M. Roberts. Cambridge Chest Clinic: Dr. M. J. Greenberg, Dr. P. K. Barrett. Cardiff Chest Clinic: Dr. S. H. Graham, Dr. H. A Evans. Croydon Chest Clinic: Dr. R. H. J. Fanthorpe. Dr. H. Clat Clinic: Dr. J. P. V. Rigby Dr. J. A. Pollock. Doncaster Deptford Chest Chinic: Dr. . P. Holden. Ealing Chest Clinic: Dr. H. Chest Clinic: Dr. F. C. N. Holden. Ealing Chest Clinic: Dr. H. Climie, Dr. G. Beven. East Ham Chest Clinic: Dr. A. Hanson, Dr. A. Q. M. B. Choudhury, Dr. W. Scott. Bdmonton Chest Clinic: Dr. R. S. Francis. Epping Chest Clinic: Dr. V. U. Lutwyche. Farnworth Chest Clinic: Dr. J. L. Armour. Finchley Chest Clinic: Dr. B. A.

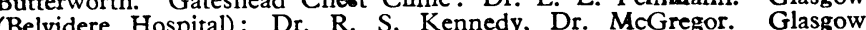
(Knightswood Hospital): Dr. G. Johnston. Hammersmith Chest Clinic: Knightswood Hospital): Dr. G. Hitchin Chest Clinic: Dr. N. McDonald, Dr. P. Stradling, Dr. S. Lal. Hitchin Chest Clinic: Dr. N. McDonald, Dr. M. A. Erooga. Hull Chest Clinic: Dr. R. Hendy, Dr. O. G. Jones. Ipswich Chest Clinic: Dr. D. P. Embleton. Kingston Chest Clinic: Dr. C. O. Edwards. Leicester Chest Clinic: Dr. C. M. Connolly. Lewisham Chest CHnic: Dr. M Farquarson. Liverpool (North) Chest Clinic: Dr. Chest Clinic: Dr. R. G. Prosser-Evans. Nottingham Chest Clinic: Dr. S. Crost Clinic: Dr. J Glyn Cox Preston Chest Clinic: Dr. W. Griffel. Reading Chest Clinic: Dr. A. J. Karlish, Chest Clinic: Dr. Dr. P. K. Hammick. Rochdale Chest Clinic: Dr. S. Thompson. Sheffield Chest O'Regan. Romford Chest Clinic: Dr. S. Thompson. Sheffietd Chest Clinic: Dr. D. H. Anderson, Dr. R. H. Townsend. Shoreditch Chest
Clinic: Dr. W. F. Richards. Southend Chest Clinic: Dr. E. G. SitaLumsden. Sunderland Chest Clinic: Dr. C. H. N. Bates, Dr. D. M. Calvert. Sutton Chest Clinic: Dr. H. F. Harwood. Swansea Chest Clinic: Dr. T. W. Davies, Dr. G. L. Lewis. Thurrock Chest Clinic: Dr. J. T. Brown, Dr. D. D. MacDonald. Tonbridge Chest Clinic: Dr. R. G. May, Dr. S. J. Sutton. Uxbridge Chest Clinic: Dr. J. T. Nicol R. G. May, R. C. Riches. Warrington Chest Clinic: Dr. R. M. White. Woe, Dr. H. R. Chest Clinic: Dr. A. R. Somner, Dr. A. A. Brace. West Hartlepool (Brierton Hospital and Chest Clinic): Dr. J. B.
Robinson, Dr. D. J. Brewer. Willesden Chest Clinic: Dr. C. H. C. Toussaint, Dr. J. R. Mikhail. Wolverhampton Chest Clinic: Dr. J. Aspin, Dr. L. E. Tyler.

The bacteriologists who carried out the sputum examinations are listed below, together with the names of the peripheral laboratories concerned (see text).

Dr. J. G. Alexander, Western General Hospital, Hull. Dr. E. A. Atkinson, Oldchurch Hospital, Romford. Dr. H. R. Cayton, Public Health Laboratory, Bristol. Dr. R. T. Cooke, General Hospital, West Hartlepool. Dr. D. M. H. Cogman, Barnet General Hospital, Barnet. Dr. P. B. Crene, Public Heath Laboratory, Sunderland. Dr. J. M. S Dixon, Public Hoalth Laboratory, Ipswich. Dr. J. B. Enticknap, East Ham Memorial Hospital, Forest Gate. Dr. E. H. Gillespie, Public Health Laboratory, Sheffeld. Dr. G. S. Graham, Whinney House Hospital, Gateshead. Dr. G. E. Greenwood, Royal Infirmary, Bolton. Dr. J. D. Gateshead. Dr. G. E. Greenwood, Royal Infirmary, Bolton. Dr. J. D. Hospital, Wolverhampton. Dr. C. N. Iland, Ayrshire Area Laboratory, Irvine. Dr. Jennings, Altrincham General Hospital. Dr. C. D. Jobling Preston, North Shields. Dr. W. S. Killpack, King Edward Memorial Hospital, Ealing, London. Dr. G. J. G. King, Public Health Laboratory, Boscombe. Dr. W. Kwantes, Public Health Laboratory, Swansea. Dr. H. Lederer, Doncaster Royal Infirmary, Doncaster. Dr. L. A. Little Public Health Laboratory, Wakefield. Dr. N. S. Mair, Public Health Laboratory, Leicester. Dr. G. B. Manning, Royal Infirmary, Bolton. Laboratory, Leicester. Dr. G. B. Manning, Royal Infirmary, Bolton.
Dr. T. D. M. Martin, Royal Berkshire Hospital, Reading. Dr. A. A. Miller, Royal Inkrmary, Preston. Dr. E. R. Mitchell, Public Health Laboratory, Nottingham. Dr. D. A. Mitchison, Hammersmith Hospital. Dr. D. B. Mossman, Warrington General Hospital, Warrington. Dr. J. Nagington, Public Health Laboratory, Cambridge. Dr. R. A. M. Oliver, Croydon Group Pathological Laboratories, Thornton Heath. Dr. W. Picton, Hillingdon Hospital, Uxbridge. Dr. L. Potaschmacher, St Andrew's Hospital, Billericay. Dr. E. W. Price, Yardley Green Hospital, Birmingham. Mr. H. C. Purdie, Knightswood Hospital, Glasgow, Dr. T. R. E. Richardson, King Edward Memorial Hospital, Ealing, London. Mr. W. Rose, St. Leonard's Hospital, London. Dr. J. A. Rycroft, Public Health Laboratory, Southend. Dr. B. J. Stephens, St. David's Hospital, Cardiff. Dr. Shrigley, Dr. S. Szutowicz, Birch Hill Hospital, Rochdale. Dr. A. W. Taylor, Tonbridge Hospital. Dr. C. E. D. Taylor, Centra Public Health Laboratory, Colindale. Dr. C. Thomas Miller, General Hospital, London. Dr. P. J. Taylor, Aintree Hospital, Liverpool. Dr. J. E. Tinne, Belvidere Hospital, Glasgow. Dr. J. R. B. Williams, The Lister Hospital, Hitchin.

\section{REFERENCES}

British Tuberculosis Association (1960). Brit. med. 7., 1, 297. (1961). Ibid., 2, 979.

Mackie, T. J., and McCartney, J. E. (1960). Handbook of Bacteriology, 10 th ed., edited by R. Cruickshank, p. 402. Livingstone, Edinburgh.

May, J. R. (1958). In Recent Trends in Chronic Bronchitis, pp. 88-99. edited by N. C. Oswald. Lloyd-Luke, London.

and May, D. S. (1963). Tubercle (Lond.), 44, 162.

\title{
Premixed Gas and Oxygen for Midwives
}

\author{
C. W. GALE, ${ }^{\star}$ M.R.C.O.G ; M. E. TUNSTALL, $†$ M.B., B.S., F.F.A. R.C.S., D.OBST.R.C.o.G. \\ C. C. WILTON-DAVIES, $\ddagger$ M.A.
}

Brit. med. F., 1964, 1, $732 \cdot 736$

In recent years it has been more widely appreciated that even a mild degree of maternal hypoxia in labour may have an adverse effect on the foetus: this is especially true in cases where placental insufficiency may be suspected. It has long been the practice to discontinue gas and air analgesia during labour if any signs of foetal distress appear, because the mother's $\mathrm{O}_{2}$ tension while breathing "gas and air" is lowered. Cole and Nainby-Luxmore (1962) drew attention to the decreased arterial $\mathrm{O}$, saturation found in labouring women receiving gas and air analgesia. They also found considerable variation in the amount

\footnotetext{
* Senior Registrar and Tutor, Institute of Obstetrics and Gynaecology, Hammersmikh Hospital, London.

Hammersminh Hother Aberdeen Royal Infirmary.

† Consultant the British Oxygen Company Ltd.
}

of $\mathrm{O}_{2}$ delivered by apparently well-maintained gas and air machines in the Oxford area.

The Central Midwives Board (1963b) are reviewing their policy with regard to the administration of inhalational analgesics by midwives, with particular reference to the possible approval of $\mathrm{N}_{2} \mathrm{O}$ and $\mathrm{O}_{2}$ apparatuses for use by midwives on their own responsibility.

The Central Midwives Board (1963a) have been reliably informed that the administration of a fixed mixture of $50 \% \mathrm{~N}_{2} \mathrm{O}$ and $50 \% \mathrm{O}_{2}$, provided it is delivered from an adequately tested and calibrated machine, is safe for unsupervised use by midwives, gives efficient analgesia, and may be substituted, where practical, for gas and air analgesia ; also that there is no significant differ- 